Biol. Stud. 2016: 10(3-4); 155-164 • DOI: https://doi.org/10.30970/sbi.1003.489

www.http://publications.Inu.edu.ua/journals/index.php/biology

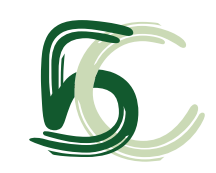

UDC 598.257 .047

\title{
STRUCTURE OF BREEDING BIRD COMMUNITIES IN URBAN AND SUB-URBAN GREEN AREAS OF LVIV CITY WITH DIFFERENT DEGREE OF ANTHROPOGENIC PRESSURE
}

\author{
G. Kuzyo \\ State Museum of Natural History, NAS of Ukraine, 18, Teatralna St., Lviv 79008, Ukraine \\ e-mail: KuzyoHanna@smnh.org
}

Difference in structure of breeding bird communities in the habitats with varying degrees of human activity is considered. Hemeroby classification, taking into account the cumulative effects of many factors on the habitat was applied. According to this classification, the model plots in Lviv city and suburbs areas belong to groups of oligo-, meso-, $\alpha$-eu- and $\beta$-euhemerobic habitats. It is established that on the investigated territory, there is no inverse relationship between the rates of species richness and degree of anthropogenic pressure. The highest values of biodiversity are inherent to oligohemerobic habitats with minor anthropogenic impacts and $\beta$-euhemerobic habitats with continuous and strong anthropogenic impacts. The number of breeding species in all $\beta$-euhemerobic plots $(N=58)$ is even greater than on oligohemerobic plots $(N=40)$. The lowest indices of biodiversity and breeding density were found on $\alpha$-euhemerobic areas. Differences were found when comparing forest habitats of oligo- and mesohemerobic groups. In the mesohemerobic habitats, there are fewer species $(N=22)$ and lower average breeding density (32.7 pairs/10 ha), while both oligohemerobic areas these are $\mathrm{N}=33$ and 50.2 pairs/10 ha respectively. Indices of Shannon, Margalef and Menghini also have lower values for the mesohemerobic areas, and dominance index of Berger-Parker, on the contrary, is higher. Unlike the mesohemerobic habitats in the oligohemerobic habitats breeding species listed in the Red Book of Ukraine were observed. Thus, in more intensively loaded forests there is a depletion of biodiversity is observed. Environmental groups differ by the way of breeding due to more cavity-nesting species in the oligohemerobic habitats; by foraging substrate - due to a greater part of urbanized species in the mesohemerobic habitats.

Keywords: breeding ornithofauna, gradient of urbanization, hemeroby, urban, suburban zone, ecological groups.

\section{INTRODUCTION}

Residential development leads to inevitable urban sprawl and is connected with landscape transformation. Those ecosystems that remained in the cities are suffering of permanent anthropogenic influences. Evaluation of current state of non-urbanized arable and forest areas of significant natural and social value are actual nowadays. We

ISSN 1996-4536 (print) • ISSN 2311-0783 (on-line) • Біологічні Студії / Studia Biologica • 2016 • Том 10/№3-4 • С. 155-164 
should understand how habitats and communities of living organisms are transformed by the anthropogenic factors.

The impact of human activity in cities and their outskirts can be estimated using the gradient paradigm. From city center to suburbs anthropogenic pressure on natural ecosystems strongly changes. Mosaic habitats remaining in the city suffer from increasing recreational load, and this concern to a suburban zone which contains both artificial and natural habitats. To systematize such disparate anthropogenically transformed habitats, Jalas [8] developed habitat classification system by a degree of hemeroby. It was used to analyze an anthropogenic influence on urban vegetation [11].

According to Kowarik [11], hemeroby (from Greek hemeros - cultivated and bios life) is a result of the cumulative human impact on the ecosystem. It includes all the consequences that occur as a result of both intended and unintended anthropopressure [10]. Hemeroby degrees express the intensity, duration, and range of human impacts. Depending on the structural and functional organization and the increase of hemeroby level, there are 6 classes of ecosystems [12].

In Lviv city and its outskirts, there are non-built territories with different level of transformation. This is an opportunity to compare breeding bird communities on such different model plots that are located in close vicinity. The city is growing and the anthropogenic pressure is growing too, and we should understand changing tendencies of the ornithofauna in urban territories.

\section{MATERIALS AND METHODS}

In the suburban zone, there were 13 model plots and 2 plots in the city for comparison. Designation of hemeroby levels in the study area was done according to the classification of Kowarik [11], adapted by Kucheryavyj [11] (Table 1). Ahemerobic plots are not presented in our study because natural habitats are absent on the territory of the city. Poly- and metahemerobic habitats were not studied because we are analyzing breeding ornithofauna of remained non-built plots on the territory of the city and suburbs.

Natural habitats which are exposed to the least anthropogenic impact (oligohemerobic) are represented in Lviv suburban zone by the beech woods of Vynnyky forest, forest reserve "Chortova skelya", Brukhovychi and Bilogorscha forests. These woodlands located in the southern and northern outskirts of the city are popular destination for residents of Lviv and the inhabitants of neighboring villages. However, a degree of the anthropogenic pressure on warious parts of these forests is different.

Bryukhovychi forest is located on the hills of Roztochya wasted within major European watershed. The whole forest is located between Lviv and villages Bryukhovychi and Velyki Hrybovychi. In the northwest, Bryukhovychi forest borders the Forest "Gryada". Main forest forming species - Fagus sylvatica, Pinus sylvestris and Quercus robur, which form mixed or pure stands [1].

To the southeast of the city so-called Davydiv strand of the geographical area Podilsk Hill Ridge extends. We laid two model plots in Vynnyky woodland and forest reserve "Chortova skelya". Overall, the area is dominated by old beech forest stands with plantings of oak, hornbeam and pine. This area is used for forest management and recreation.

Bilogorscha forest connects Levandivska residential area with Bilohorshcha village causing constant attendance. A part of Bilogorscha forest is presented by hornbeam planting with marshy inaccessible areas. Another part is presented by plantings of cypress, pine and birch. Small lakes and streams are located in the forest.

ISSN 1996-4536 (print) • ISSN 2311-0783 (on-line) • Біологічні Студії / Studia Biologica • 2016 • Том 10/№3-4 • С. 155-164 


\section{Table 1. Classification of model plots by the hemeroby levels}

\section{Таблиця 1. Класифікація модельних ділянок за шкалою гемеробії}

\begin{tabular}{|c|c|c|c|}
\hline Hemeroby level & $\begin{array}{l}\text { The intensity of human } \\
\text { impact }[8,10]\end{array}$ & $\begin{array}{c}\text { Examples of habitats } \\
{[11,12]}\end{array}$ & Model plots \\
\hline Ahemerobic & $\begin{array}{l}\text { Non-cultivated } \\
\text { habitats with Lack of } \\
\text { anthropogenic impact }\end{array}$ & $\begin{array}{l}\text { Virgin forests, bogs, } \\
\text { rock vegetation, alpine } \\
\text { meadows, etc. }\end{array}$ & None \\
\hline Oligohemerobic & $\begin{array}{l}\text { Minor anthropogenic } \\
\text { impacts which do not } \\
\text { modify the substrate }\end{array}$ & $\begin{array}{l}\text { Forests of first and } \\
\text { second category, } \\
\text { meadows, ponds and } \\
\text { swamps with prominent } \\
\text { anthropogenic influence }\end{array}$ & $\begin{array}{l}\text { Bryukhovychi forest; } \\
\text { Vynnyky forest; forest } \\
\text { reserve "Chortova } \\
\text { skelya"; Bilogorscha } \\
\text { forest }\end{array}$ \\
\hline Mesohemerobic & $\begin{array}{l}\text { Weak to moderate, or } \\
\text { periodic anthropogenic } \\
\text { factors }\end{array}$ & $\begin{array}{l}\text { Urban parks and city } \\
\text { squares }\end{array}$ & $\begin{array}{l}\text { "Zubra" and "Citadel" } \\
\text { parks }\end{array}$ \\
\hline$\beta$-Euhemerobic & \multirow{2}{*}{$\begin{array}{l}\text { Continuous and strong } \\
\text { anthropogenic impacts } \\
\text { causing modifications of } \\
\text { the substrate }\end{array}$} & \multirow{2}{*}{$\begin{array}{l}\text { Cultivated agricultural, } \\
\text { horticultural and } \\
\text { domestic habitats, } \\
\text { gardens and orchards }\end{array}$} & $\begin{array}{l}\text { Allotment gardens; } \\
\text { fruit orchard; peatbog; } \\
\text { sludge beds }\end{array}$ \\
\hline$\alpha$-Euhemerobic & & & $\begin{array}{l}\text { Fields near Sokilnyky; } \\
\text { fields near Zubra; } \\
\text { pasture near Zubra; } \\
\text { meadow near } \\
\text { Bilohorshcha }\end{array}$ \\
\hline Polyhemerobic & $\begin{array}{l}\text { Continuous and very } \\
\text { strong anthropogenic } \\
\text { impacts }\end{array}$ & $\begin{array}{l}\text { Careers slagheaps, } \\
\text { levees, landfills, etc. }\end{array}$ & None \\
\hline Metahemerobic & $\begin{array}{l}\text { Continuous impact of } \\
\text { anthropogenic factors that } \\
\text { are so strong they exceed } \\
\text { the tolerance of plants }\end{array}$ & $\begin{array}{l}\text { Dead surface of cities } \\
\text { and industrial centers }\end{array}$ & None \\
\hline
\end{tabular}

There are mesohemerobic model plots, namely "Zubra" and "Citadel" parks. Bilogorscha forest, as well as "Zubra" park is adjacent to the residential area but there are no remote places and the attendance is much higher. "Citadel" park was planted in the 70 's. It is located on a hill in the center of the city and contains many buildings on its territory. A degree of disturbance compared to other model plots is the largest. An additional factor is night lighting in the park.

Among $\beta$-euhemerobic plots, there are allotment gardens, fruit orchard, peat bog, and sludge beds near Poltva river. In the 70's allotments were created and began to be used. The orchard was founded in 1948, and in 1953 it was passed to Kyiv Research Institute of Horticulture, but later it became unprofitable [22]. At present the garden is not used and its current state is very abandoned. The peatbog "Bilohorshcha" belonging to Roztochya region is situated in the western outskirts and was one of the most valuable monuments of nature before the industrial peat extraction in 50's. The research was also conducted in sludge beds in the north-eastern outskirts.

Among the studied territories, $\alpha$-euhemerobic group includes highly modified plots by the agricultural activity. There are mixed crops and bare tilled lands near Sokilnyky village. On the abandoned pasture near Zubra village, cattle graze but virtually the entire 
area is overgrowing with ruderal species. During the observation period (2013-2015), every year there were spring burnings of dry herbs. In the western outskirts of the city next to the village Bilohorshcha, there are marshy hay meadows and pasture. After the cessation of peat industry this area was drained. Presently, manually mowing and cattle grazing are carried.

The work is based on a material collected in the field during the breeding season in 2015. For establishing of species composition, number, and density of breeding birds, the line transects method was used [3].

A description of bird communities was made after Belik [2] with modifications by Skilskyy [17]. Types of avifauna are listed by Shtegman [19]. To establish trophic groups, we used materials of Bank of zoogeographic data of Institute of Systematics and Ecology of Animals, Siberian Branch of RAS.

The value of species in the community is represented by dominants $(10 \%$ and more), subdominants (1-9 \%) and satellite (lower than $1 \%$ ). All common and abundant species of birds with breeding density more than 1 pair/10 ha were considered as typical. Distribution of birds by abundance categories carried after Kuzyakin [13]:

- Abundant (10-99 pair/10 ha);

- Common (1-9 pair/10 ha);

- Frequent (0.1-0.9 pair/10 ha);

- Occasional (0.01-0.09 pair/10 ha);

- Rare (0.001-0.009 pair/10 ha).

For comparison of the ornithofauna of model plots species lists, breeding density and several generally accepted indices that express the relationship between a number of species and their significance in the community were used. Shannon index takes into account species richness and proportion of each species within the local aquatic community. Menghini and Margalef indices characterize the relative number of species. The Berger-Parker index equals a proportional abundance of the most abundant type. We also calculated the number of species that make up $50 \%$ of total group multiplicity and breeding density on the model plots.

\section{RESULTS AND DISCUSSION}

Habitats of different hemeroby degree vary in terms of indices of species richness. Menghini and Margalef indices have the lowest value on $\alpha$-euhemerobic plots, especially in the fields near Sokilnyky (Fig. 1). A high value of Berger-Parker index (Fig. 2) is the most distinct. This plot is farmed every year, unlike the rest. Only 5 species breed here and they nest hedges. Index of dominance is the biggest on this plot (0.29) and the total proportion of the dominant species is $85.7 \%$. In general, such low values of species richness are typical for $\alpha$-euhemerobic habitats.

The greatest number of species was found in the oligo- and $\beta$-euhemerobic habitats, in particular in Bilogorscha forest (37 species) and on sludge beds near Poltva river (35 species). Overagely, 33 species were observed in the oligohemerobic habitats, and 29 species in $\beta$-euhemerobic. It is also true for indices of species richness (Shannon, Menghini, and Margalef) - their significance is the largest in the oligo- and $\beta$-euhemerobic habitats (Table 2). Higher values of breeding density and species richness indices are expected on oligohemerobic habitats, as they are close to natural habitats. But $\beta$-euhemerobic plots are represented by the ecotonic habitats where the biodiversity is greater due to combining of different conditions - water bodies, open landscapes, bushes, shrubs

ISSN 1996-4536 (print) • ISSN 2311-0783 (on-line) • Біологічні Студії / Studia Biologica • 2016 • Том 10/№3-4 • С. 155-164 
and forest plantations $[16,23]$. It is important to note that the total list of species which breed on $\beta$-euhemerobic plots is bigger (58 species in total), than on the oligohemerobic (40 species). In addition, in the oligohemerobic habitats species which were not found on other sites were identified: Marsh Harrier (Circus aerogenosus), Montagu's Harrier (Circus pygagrus), Kestrel (Falco tinnunculus), Reed Warbler (Acrocephalus scirpaceus), Bluethroat (Luscinia svecica), Savi's Warbler (Locustella luscinioides), Redstart (Phoenicurus phoenicurus), Penduline Tit (Remiz pendulinus), Bittern (Botaurus stellaris), Moorhen (Gallinula chloropus), Coot (Fulica atra), and Redshank (Tringa totanus). Among them, Montagu's Harrier, Kestrel and Bittern are regionally rare species [7].
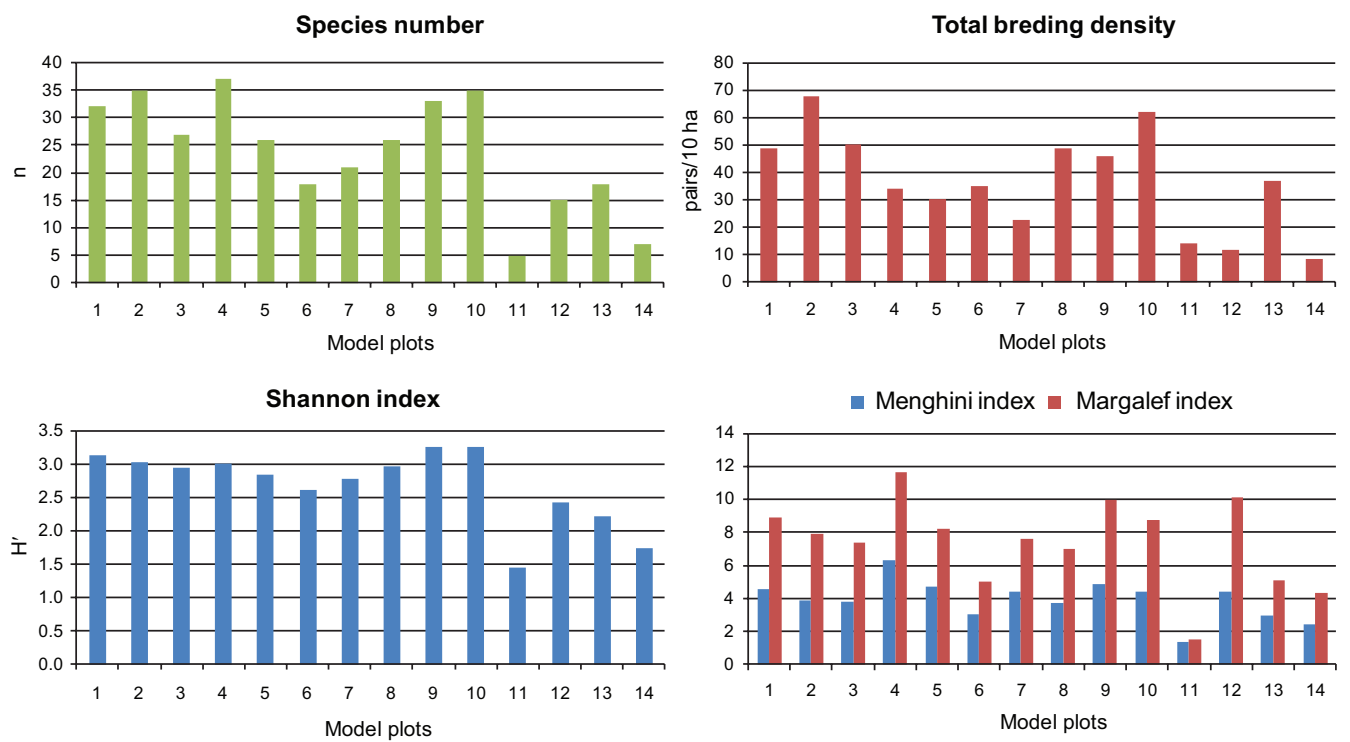

\begin{tabular}{|c|c|c|c|c|}
\hline \multirow[t]{7}{*}{ Model plots: } & 1 & Bryukhovychy forest & 8 & Allotment gardens \\
\hline & 2 & Vynnyky forest & 9 & Peatbog \\
\hline & 3 & forest reserve & 10 & Sludge beds \\
\hline & 4 & Bilogorshcha forest & 11 & Fields near Sokilnyky \\
\hline & 5 & "Zubra" park & 12 & Meadow near Bilohorshcha \\
\hline & 6 & "Citadel" park & 13 & Pasture near Zubra \\
\hline & 7 & Fruit orchard & 14 & Fields near Zubra \\
\hline
\end{tabular}

Fig. 1. The values of species number, total density, and indices of Shannon Menghini and Margalef on model plots

Рис. 1. Значення кількості видів, загальної щільності гніздування й індексів Шеннона, Менхініка та Маргалефа на модельних ділянках

The total breeding density is the largest on oligohemerobic plots (on average 50 pairs/10 ha). The lowest number of species was found in the $\alpha$-euhemerobic habitats (on average 11 species) (Table 2).

4 hemerobic groups presented in our study include a variety of habitats that explains differences in breeding ornithoauna. Therefore we decided to compare the same type of forest habitats within oligo- and mesohemerobic groups, that differ mainly by a degree of the anthropogenic pressure.

In city parks (mesohemerobic group), much less breeding species (22) were found than in suburban forests which belong to oligohemerobic group (33 species). In meso- 
hemerobic habitats, biodiversity indices are lower and the dominance index is higher (Table 2). It confirms that intensive recreation leads to depletion of the biodiversity in forests [14]. Oligohemerobic habitats contain unfrequented old forest areas which provide breeding conditions for a large number of cavity-nesting species, including those listed in the Red Book of Ukraine: Green Woodpecker (Picus viridis), White-backed Woodpecker (Dendrocopos leucotos), Stock Dove (Columba oenas), Ural Owl (Strix uralensis) and regionally-rare Red-breasted Flycatcher (Ficedula parva).
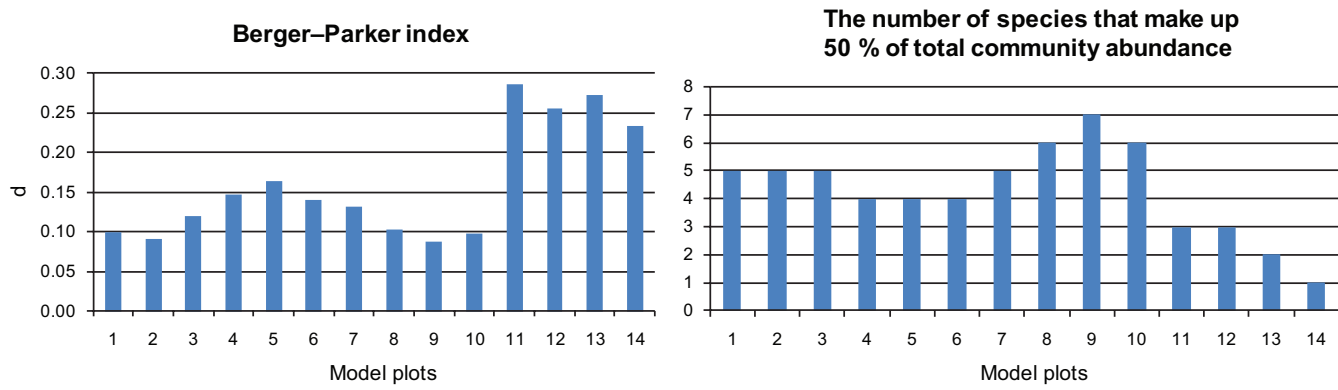

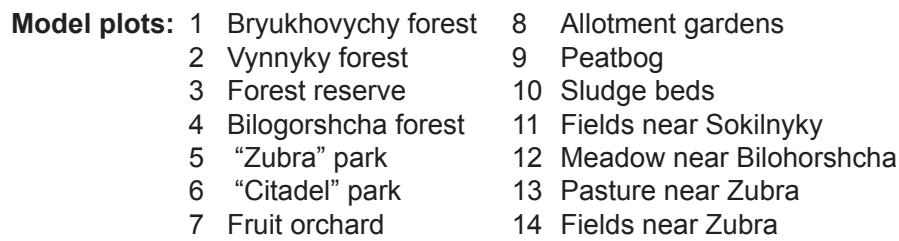

Fig. 2. The values of Berger-Parker index and the number of species that make up $50 \%$ of total group multiplicity and breeding density on the model plots

Рис. 2. Значення індексу Берґера-Паркера і числа видів, які сумарно становлять 50 \% чисельності угруповання та щільності гніздування на модельних ділянках

Table 2. The average values of statistical parameters of different groups due to their assignment to the hemeroby levels

Таблиця 2. Усереднені значення статистичних показників різних груп біотопів за ступенем гемеробії

\begin{tabular}{|l|c|c|c|c|c|c|c|}
\hline Hemeroby level & $\mathrm{n}$ & $\mathrm{D}$ & $\mathrm{H}^{\prime}$ & $\mathrm{D}_{\mathrm{M}}$ & $\mathrm{D}_{\mathrm{Mg}}$ & $\mathrm{d}$ & $\mathrm{S}_{50}$ \\
\hline Oligohemerobic & $33 \pm 3.7$ & $50.25 \pm 11.9$ & $3.03 \pm 0.07$ & 4.65 & $8.94 \pm 1.65$ & $0,11 \pm 0,02$ & $5 \pm 0.43$ \\
\hline Mesohemerobic & $22 \pm 4$ & $32.71 \pm 2.3$ & $2.72 \pm 0.12$ & $3.88 \pm 0.84$ & $6.63 \pm 1.59$ & $0.15 \pm 0.01$ & 4 \\
\hline$\beta$-Euhemerobic & $29 \pm 5.6$ & $44.83 \pm 14.1$ & $3.06 \pm 0.20$ & $4.36 \pm 0.42$ & $8.32 \pm 1.14$ & $0.10 \pm 0.02$ & $6 \pm 0.71$ \\
\hline$\alpha$-Euhemerobic & $11 \pm 5.4$ & $17.77 \pm 11.1$ & $1.96 \pm 0.38$ & $2.77 \pm 1.10$ & $5.26 \pm 3.10$ & $0.26 \pm 0.02$ & $2 \pm 0.83$
\end{tabular}

Comments: $\mathrm{n}$ - the number of species; $\mathrm{D}$ - total density of breeding pairs (pairs/10 ha); $\mathrm{H}^{\prime}$ - Shannon index; $D_{M}-$ Menghini index; $D_{M g}-$ Margalef index; $d$ - Berger-Parker index; $S_{50}-$ the number of species that make up $50 \%$ of total multiplicity group

Примітки: n - кількість видів; D - загальна щільність гніздових пар (пар/10 га); Н' - індекс Шеннона; $\mathrm{D}_{\mathrm{M}}$ - індекс Менхініка; $\mathrm{D}_{\mathrm{Mg}}$ - індекс Маргалефра; d - індекс Берґера-Паркера; $\mathrm{S}_{50}-$ число видів, які сумарно становлять 50 \% чисельності угруповання

An average proportion of cavity-nesting species on the oligohemerobic plots is $43 \%$ (15 species), and on the mesohemerobic plots - $31 \%$ (9 species). Among them, 
the most distinguished is a proportion of one of the dominant in both habitat groups the cavity-nesting species Collared Flycathcer (Ficedula albicollis): in the oligohemerobic habitats, it's $7.3 \%$ and in the mesohemerobic $-4.6 \%$.

Unlike Collared Flycathcer, the proportion of other dominant species - Great Tit (Parus major) increases on a gradient of urbanization: $8.4 \%$ in oligohemerobic and $12.14 \%$ in mesohemerobic habitats, because it is ecologically plastic species adapted to life even in highly urbanized territories.

Among crown-breeders in oligohemerobic habitats, there are species of the upper trophic level - Common Buzzard (Buteo buteo), Ural Owl (Strix uralensis) and Raven (Corvus corax). Most of carnivorous and omnivorous birds are most sensitive to the effects of urbanization group [5].

Ecological groups by the foraging substrate also differ in the two groups of habitats. In mesohemerobic habitats, a proportion of ground foragers is higher (48\%) than in the oligohemerobic (28\%). The reason for that is greater proportion of the following species: Blackbird (Turdus merula), Song Thrush (Turdus philomelos), Fieldfare (Turdus pilaris), Woodpigeon (Columbs palumbus) and Magpie (Pica pica) in the mesohemerobic habitats. All these species have formed proportion populations in Lviv, so their breeding density in the city parks is higher than in natural forests $[4,9,15,17,21,22]$.

\section{CONCLUSIONS}

Among 14 model plots in Lviv urban and suburban zone, there were highlighted 4 habitat types by a degree of the hemeroby: oligo-, meso-, $\beta$-eu- and $\alpha$-euhemerobic. The gradual decrease of species richness and biodiversity indices along this urbanization gradient, indicates a sensitivity of breeding birds to the anthropogenic pressure.

High value of natural and ecotone sites (oligohemerobic and $\beta$-euhemerobic biotopes respectively) is reflected in the highest values of species richness, total breeding density and biodiversity indices.

The spatial-typological structure of bird communities predictably varies by the degree of the hemeroby. This is not only based on the ecological needs of birds species in different biotopes, but also under the influence of the anthropogenic pressure that is evident when comparing similar oligo- and mesohemerobic habitats. These biotopes contain species listed in the Red Book of Ukraine and upper trophic level species - the representatives of the Falconiformes and Strigiformes order that are a sensitive element of bird communities [5].

In the gradient of urbanization, ecological groups by the way of nesting and foraging are gradually changing. Oligohemerobic habitats provide breeding for greater abundance and number of cavity-nesting species. In the mesohemerobic habitats due to large proportion of urban breeders, structure of communities by the foraging substrate is shifted from foliage-gleaners to ground foragers. Thus, more urban territories loose species which regulate a number of tree pests. The research should be continued because of actuality of urgency of monitoring the transformed territories.

\section{ACKNOWLEDGEMENTS}

The author is grateful to supervisor A.A. Bokotey and to J.J. Shrubovych for consultations and valuable advices at writing this article.

ISSN 1996-4536 (print) • ISSN 2311-0783 (on-line) • Біологічні Студії / Studia Biologica • 2016 • Том 10/№3-4 • C. 155-164 
1. Babych O. Geological conditions of forest geosystems Lviv's suburban area. Visnyk of Ternopil University. Biological Series, 2010; 27(1): 278-283. (In Ukrainian).

2. Belik V. P. Steppe birds Pridonya: formation, anthropogenic transformation and protection issues. Rostov-on-Don, 2000. 276 p. (In Russian).

3. Bibby C.J., Burgess N.D., Hill D.A., Mustoe S.H. Bird Census Techniques, $2^{\text {nd }}$ ed. London: Academic Press, 2000.

4. Bokotey A.A. The number of thrushes of Lviv and their bioindication role. The problems of urban ecology and phytomelioration: proceedings of the scientific conference. Lviv, 1991. 118 p. (In Ukrainian).

5. Chacea J.F., Walsh J.J. Urban effects on native avifauna: a review. Landscape and Urban Planning, 2006; 74: 46-69.

6. Debrinyuk Yu.M., Prydka P.P. Forest stand of Ukrainian Roztochya: areal, silvicultiral and biometric features. Scientific Bulletin of UNFU, 2013; 23(16): 9-22. (In Ukrainian).

7. Gorban I., Gorban L.,Kyjko A. Regionally rare species of birds. Visnyk of Lviv University. Biological Series, 2006; 42: 3-14. (In Ukrainian).

8. Jalas, J. Hemerobe und hemerochore Pflanzenarten. Ein terminologischer Reformversuch, [Hemerobic and hemerochoric and plant species. An attempt of a terminological reform]. Acta Societatis pro Fauna et Flora Fennica, 1955, 72, 1-15.

9. Khornyak M. Synurbization of Woodpigeon (Columba palumbus L.) in Lviv. Visnyk of Lviv University. Biological Series, 2003; 34: 173-179. (In Ukrainian).

10. Kiedrzynski M., Kiedrzynska E., Witoslawski P. et al. Historical land use, actual vegetation, and the hemeroby levels in ecological evaluation of an urban river valley in perspective of its rehabilitation plan. Pol. J. Environ. Stud, 2014; 23(1): 109-117.

11. Kowarik I. Some responses of flora and vegetation to urbanization in Central Europe. In: Sukopp H. et al. (Eds) Urban Ecology. Hague: Academic Publishing, 1990. P. 45-74.

12. Kucheryavyj V. Sustainable development: global, regional and local problems of environmental management. Proceedings of Shevchenko Scientific Society. Environmental Problems and Biodiversity Lviv Region, 2001: 19-27. (In Ukrainian).

13. Kuzyakin A.P. Zoogeography of USSR. Proceedings of Moscow Pedagogical Institute named after N.K. Krupskaya, 1962; 109(1): 3-182. (In Russian).

14. Nielsen A., van den Bosch M., Maruthaveeran S., van den Bosch C. Species richness in urban parks and its drivers: A review of empirical evidence. Urban Ecosyst, 2014; 17: 305-327.

15. Pasichnyk A.O. Nest placing of the Magpie in Lviv. Berkut, 1995; 4(1-2): 47-49. (In Ukrainian).

16. Schneider S.C., Fischer J.D., Miller J.R. Two-sided edge responses of avian communities in an urban landscape. Urban Ecosystems, 2015; 18(2): 539-551.

17. Senyk M.A, Khornyak M.M. Contemporary changes in the ornithofauna of Lviv city. Berkut, 2003; 12(1-2): 9-13. (In Ukrainian).

18. Skilsky I.V. Patterns of habitat distribution of birds in Chernivtsi: spatio-temporal aspect. Berkut, 2006; 15(1-2): 81-85. (In Ukrainian).

19. Stegmann B.K. Basics ornithogeographic division Palearctic based on the study type avifauna. Izv. AS USSR. Ser. Biol, 1936; 2(3): 523-563. (In Russian).

20. Tatarynov K.A. Population structure of blackbirds in Lviv city. The study of birds of the USSR, their protection and rational use: conference proceedings. Leningrad, 1986. 267 p. (In Russian).

21. Tatarynov K.A. Synantropisation of blackbird in Western Ukraine. Vestnik Zoologii, 1988; 2: 73-74. (In Russian).

22. The history of the towns and villages of the Ukrainian SSR: The $26 \mathrm{t}$. Lviv region / Ed. Tronko P. T. Kyiv: Home Edition URE AN UkrSSR, 1968: 980 p. (In Ukrainian).

23. Tsaryk J.V., Senyk M.A., Gorban I.M. et al. Ecotones between forest and meadows as concentration centres of birds variety. Ecology and Noospherology, 2006; 17(1-2): 78-85. (In Ukrainian).

ISSN 1996-4536 (print) • ISSN 2311-0783 (on-line) • Біологічні Студії / Studia Biologica • 2016 • Том 10/№3-4 • С. 155-164 


\section{СТРУКТУРА УГРУПОВАНЬ ГНІЗДОВИХ ПТАХІВ ЗЕЛЕНИХ ЗОН ЛЬВОВА ТА ПЕРЕДМІСТЯ НА ДІЛЯНКАХ ІЗ РІЗНИМ СТУПЕНЕМ АНТРОПОГЕННОГО НАВАНТАЖЕННЯ}

Г. О. Кузьо Державний природознавчий музей НАНУ, вул. Театральна, 18, Львів 79008, Україна e-mail: KuzyoHanna@smnh.org

Розглянуто різницю структури гніздових орнітокомплексів у біотопах із різним ступенем антропогенного навантаження. Використано класифікацію гемеробії, що враховує сукупний вплив багатьох чинників на біотоп. Згідно з цією класифікацією, модельні ділянки Львова і передмістя належать до груп оліго-, мезо-, $\alpha$-еу- та $\beta$-еугемеробних біотопів. Встановлено, що на досліджуваній території немає оберненої залежності між показниками видового багатства та ступенем антропогенного пресу. Найбільші значення показників біорізноманіття притаманні олігогемеробним біотопам із невеликим антропогенним впливом та $\beta$-еугемеробним біотопам з тривалими сильними антропогенними впливами. Кількість гніздових видів на всіх $\beta$-еугемеробних ділянках ( $N=58) €$ навіть більшою, ніж на олігогемеробних $(\mathrm{N}=40)$. Найменші значення індексів біорізноманіття та щільності гніздування виявлені на $\alpha$-еугемеробних ділянках. Під час порівняння лісових біотопів оліго- та мезогемеробної групи виявили відмінності. Для мезогемеробних біотопів притаманна менша кількість видів ( $\mathrm{N}=22)$, середня щільність гніздування (32,7 пар/10 га), тоді як на олігогемеробних ділянках ці значення становлять $\mathrm{N}=33$ та 50,2 пар/10 га відповідно. Індекси Шеннона, Менхініка та Маргалефа також мають менші значення на мезогемеробних ділянках, а індекс домінування Берґера-Паркера, навпаки - більше. Також, на відміну від мезогемеробних, в олігогемеробних біотопах спостерігали на гніздуванні види, занесені до Червоної книги України. Тобто в інтенсивніше навантажених лісових насадженнях спостерігали збіднення біорізноманіття. Екологічні групи за способом гніздування відрізняються завдяки більшій кількості дуплогніздників в олігогемеробних біотопах; за ярусом збирання корму - завдяки більшій частці участі синурбійних видів у мезогемеробних біотопах.

Ключові слова: гніздова орнітофауна, градієнт урбанізації, гемеробія, місто, передмістя, екологічні групи.

\section{СТРУКТУРА СООБЩЕСТВА ГНЕЗДЯЩИХСЯ ПТИЦ ЗЕЛЕНЫХ ЗОН ЛЬВОВА И ПРИГОРОДА НА УЧАСТКАХ С РАЗНОЙ СТЕПЕНЬЮ АНТРОПОГЕННОЙ НАГРУЗКИ}

\section{Г. О. Кузьо}

Государственный природоведческий музей НАН Украины ул. Театральная, 18, Львов 79008, Украина e-mail: KuzyoHanna@smnh.org

Рассмотрена разница структуры гнездовых орнитокомплексов в биотопах с разной степенью антропогенной нагрузки. Использована классификация гемеробии, учитывающей совокупное влияние многих факторов на биотоп. Согласно этой классификации, модельные участки Львова и пригорода отнесены к группам 
олиго-, мезо-, $\alpha$-эу- и $\beta$-эугемеробных биотопов. Установлено, что на исследуемой территории нет обратной зависимости между показателями видового богатства и степенью антропогенного пресса. Наибольшие значения показателей биоразнообразия присущи олигогемеробным биотопам с небольшим антропогенным воздействием и $\beta$-эугемеробным биотопам с длительными сильными антропогенными воздействиями. Количество гнездящихся видов на всех $\beta$-эугемеробных участках ( $N=58)$ даже больше, чем на олигогемеробных $(N=40)$. Наименьшие значения индексов биоразнообразия и плотности гнездования обнаружены на $\alpha$-эугемеробных участках. При сравнении лесных биотопов олиго- и мезогемеробной группы обнаружены различия. Для мезогемеробных биотопов присуще меньшее количество видов $(\mathrm{N}=22)$ и средняя плотность гнездования $(32,7$ пар/10 га), в то время как на олигогемеробных участках эти значения составляют $\mathrm{N}=33$ и 50,2 пар/10 га соответственно. Индексы Шеннона, Менхиника и Маргалефа также имеют меньшие значения на мезогемеробных участках, а индекс доминирования Бергера-Паркера, наоборот - большее. Также, в отличие от мезогемеробных, в олигогемеробных биотопах на гнездовании наблюдаются виды, занесенные в Красную книгу Украины. То есть в интенсивнее нагруженных лесных насаждениях наблюдается обеднение биоразнообразия. Экологические группы по способу гнездования отличаются за счет большего количества дуплогнездников в олигогемеробных биотопах; за ярусом сбора корма - за счет большей доли участия синурбийных видов в мезогемеробных биотопах.

Ключевые слова: гнездовая орнитофрауна, градиент урбанизации, гемеробия, город, пригород, экологические группы.

Одержано: 04.07.2016

ISSN 1996-4536 (print) • ISSN 2311-0783 (on-line) • Біологічні Студії / Studia Biologica • 2016 • Том 10/№3-4 • С. 155-164 